\title{
Correction to: Molecular identification of Leishmania spp. isolates causes cutaneous leishmaniasis (CL) in Sanliurfa Province, Turkey, where $\mathrm{CL}$ is highly endemic
}

\author{
Gulcan Gurses ${ }^{1}$ • Mehmet Ozaslan ${ }^{2}$ • Fadile Yıldız Zeyrek ${ }^{3}$ • Ibrahim H. Kılıç ${ }^{2}$ • \\ Nebiye Yentür Doni ${ }^{1} \cdot$ I. Didem Karagoz ${ }^{2} \cdot$ Nermin Uluca $^{3}$
}

Published online: 3 January 2018

(C) Institute of Microbiology, Academy of Sciences of the Czech Republic, v.v.i. 2018

\section{Correction to: Folia Microbiol}

https://doi.org/10.1007/s12223-017-0556-1

In published article (Molecular Identification of Leishmania spp. Isolates Causes Cutaneous Leishmaniasis
(CL) in Sanliurfa Province, Turkey, Where CL is Highly Endemic) Table 1 titled "The $\mathrm{pH}$ values of yogurts collected from villages in Turkey" doesn't belong to this article. The correct Table 1 titled "Clinical characterizations of the $135 \mathrm{CL}$ patients" is presented below.
Table 1 Clinical characterizations of the 135 CL patients

\begin{tabular}{llllll}
\hline Number of lesion & $n$ & Diameter of lesion $(\mathrm{mm})$ & $n$ & Duration of lesion & $n$ \\
\hline 1 & $76(56 \%)$ & $1-5$ & $47(35 \%)$ & 15 days -2 months & $51(38 \%)$ \\
$2-3$ & $39(29 \%)$ & $6-15$ & $60(44 \%)$ & $3-5$ months & $61(45 \%)$ \\
$4-5$ & $12(9 \%)$ & $>15$ & $28(21 \%)$ & $6-11$ months & $10(7 \%)$ \\
$>6$ & $8(6 \%)$ & & & $>1$ year & $13(10 \%)$ \\
\hline
\end{tabular}

The online version of the original article can be found at https://doi.org/ 10.1007/s12223-017-0556-1.

Mehmet Ozaslan

ozaslanmd@gantep.edu.tr

Gulcan Gurses

ggurses@harran.edu.tr

Fadile Yıldız Zeyrek

fadilezeyrek@hotmail.com

Ibrahim H. Kılıç

kilic@gantep.edu.tr

Nebiye Yentür Doni

n_doni@hotmail.com

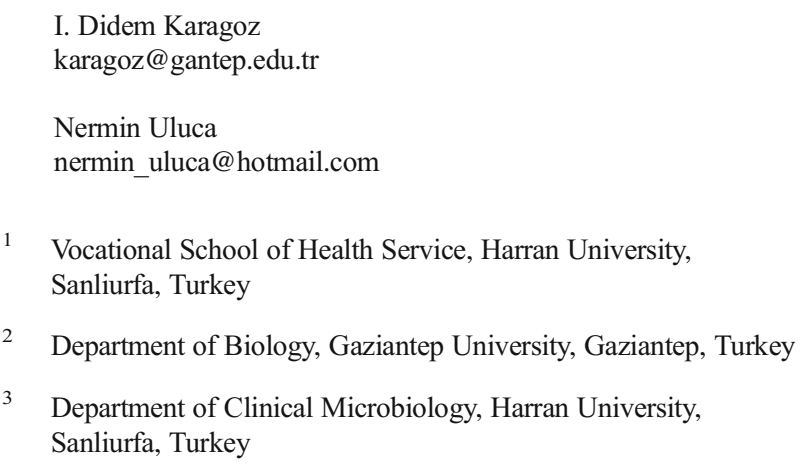

